\title{
Ewangelie jako prawdziwe świadectwo Słowa Wcielonego
}

\author{
The Gospels as True Witnesses of the Incarnated Word
}

\author{
JANUSZ KRĘCIDŁO \\ Instytut Nauk Biblijnych, Uniwersytet Kardynała Stefana Wyszyńskiego w Warszawie \\ email: oldicerkj@gmail.com \\ ORCID: 0000-0002-0913-5513
}

\begin{abstract}
Aвstract: The article develops the concept of true witness of the four canonical Gospels to Jesus Christ the Incarnated Word. The starting point is presentation of the teaching of the Pontifical Biblical Commission (PBC) in the document The Inspiration and Truth of the Sacred Scripture (2014) about the witness of the Bible, especially the Gospels. The canonical Gospels are considered in it as main witness of the life and teaching of the Incarnated Word. The article demonstrates that the PBC repeats here the teaching of the conciliar constitution Dei Verbum (1965). Argumentation in the article emphasizes the historical reliability of the transmission of the life and teaching of the historical Jesus in the Church tradition: historical Jesus - eye witnesses - written Gospels - authoritative interpretation in the Church. The canonical Gospels are not primarily literary texts but a truthful registration of the witness of faith of Jesus' believers. Consequently, the hermeneutic of faith is the only methodology that is apt to explain and understand the true nature of the Scriptures.
\end{abstract}

KEYwORDs: biblical hermeneutics, canonical Gospels, historical truth of the Gospel, witness of the Church tradition, hermeneutics of faith

SŁowA KLuCze: hermeneutyka biblijna, Ewangelie kanoniczne, historyczna prawda Ewangelii, świadectwo tradycji Kościoła, hermeneutyka wiary

$\mathrm{N}$ a początku należy wyjaśnić, jak definiujemy pojęcia użyte w tytule tego artykułu. Pod terminem „Ewangelie” rozumiemy cztery Ewangelie - Mateusza, Marka, Łukasza i Jana - uznane przez autorytet Kościoła za kanoniczne i natchnione przez Boga. Przymiotnik ,prawdziwe” odnosimy tu do klasycznego rozumienia prawdy - prawdziwe, tzn. zgodne z rzeczywistością ${ }^{1}$. Określony tym

1 Ks. prof. Henryk Witczyk wylicza następujące cztery teorie (podejścia do) prawdy: „,- klasyczna teoria: prawda jako adaequatio intellectus et rei; - teoria ujmująca prawdę jako a-letheia (odsłonięcie się bytu, jako to, co pokazuje się z samej istoty danego bytu); - koherentna teoria prawdy, w której decydujące znaczenie ma brak sprzeczności i zgodność systemu; - intersubiektywna i kontekstualna teoria prawdy, w której zwraca się uwagę na praktyczny wymiar języka i podkreśla, że prawda w ogromnej mierze zależy od sytuacyjnych kontekstów, w których jest wypowiadana". Zob. tenże, „Natchnienie i prawda Pisma świętego - nowe perspektywy”, Biblia w teologii fundamentalnej (red. J. Perszon) (Toruń: Wydawnictwo Naukowe Uniwersytetu Mikołaja Kopernika 2010) 173. Natomiast metodolog historii prof. Wojciech Wrzosek, idąc za Paulem Ricoeurem, wprowadza ka- 
przymiotnikiem rzeczownik ,świadectwo”, odnoszący się logicznie do terminu „Ewangelie”, oznacza spisany tekst każdej z Ewangelii, zarówno w krytycznej wersji w języku oryginalnym, jak i w przekładach zaakceptowanych przez autorytet Kościoła. Ostatnim komponentem tytułu jest wyrażenie „Słowo Wcielone", przez które rozumiemy osobę Jezusa Chrystusa, Syna Bożego, posłanego na świat przez Ojca (J 1,1-18). Podstawową linią argumentacyjną w tym artykule będzie dostarczanie przesłanek za prawdziwością, to znaczy wiarygodnością, świadectwa Ewangelii dla czytelników wszystkich czasów odnośnie do osoby i dzieła dokonanego przez Jezusa Chrystusa - Wcielonego Słowa Boga, oraz krytyczna ewaluacja poglądów zaprzeczających prawdziwości świadectwa Ewangelii o Nim.

\section{Historyczna prawda Ewangelii w nauczaniu Kościoła}

Jako że inspiracją oraz fundamentalnym punktem odniesienia do podejmowanych dyskusji jest dokument Papieskiej Komisji Biblijnej (PKB) Natchnienie i prawda Pisma Świętego, warto przytoczyć tutaj kilka passusów, które traktują o wartości i prawdziwości świadectwa Ewangelii ${ }^{2}$.

„Pomiędzy księgami Biblii chrześcijańskiej uprzywilejowane miejsce należy się Ewangeliom jako spisanemu świadectwu Bożego objawienia w jego punkcie kulminacyjnym. W nich bowiem znajdujemy samoobjawienie się Boga Ojca przez jego Syna, który stawszy się człowiekiem żył, cierpiał i umarł oraz wyniósł naszą ludzką naturę do boskiej chwały przez swe zmartwychwstanie. Konstytucja dogmatyczna O Objawieniu Bożym stwierdza: „Najgłębsza zaś prawda

tegorię prawdy metaforycznej, którą warto tu przywołać, zwłaszcza w kontekście naszego dalszego argumentowania za prawdziwością świadectwa Ewangelii na podstawie przesłanek historycznych. Wrzosek stwierdza: „Jeśli historyk wypełnia dzieje zdarzeniami, to lansuje prawdę zdarzeń, tzw. faktów. (...) Jeśli z kolei historyk nietradycyjny, np. scjentysta, bada procesy historyczne, to ustala ich trwanie, przebieg, korelacje $\mathrm{z}$ innymi procesami. Nie ma więc w polu jego zainteresowań zdarzeń (...). Nie ma więc w nim prawdy zdarzeń. Jest natomiast „prawda” o tym, jak świat był światem procesów. (...) Owo zestawienie strategii narracyjnych historyka - jak określam go klasycznego - z nieklasycznym ukazuje - w wielkim skrócie - różnicę między prawdą o przeszłości oferowaną przez jednego i drugiego. Przyjęte przez historyka klasycznego metafory historiograficzne w specyficznym ich wariancie decydują o tym, jakiej prawdy o przeszłości możemy się po nim spodziewać. To, jakiego rodzaju „byty historyczne” postrzega i tropi ich los, decyduje, z jaką ,prawdą" mamy do czynienia. Prawdy te są zdeterminowane wyborem metafor historiograficznych, jakie organizują ogląd historyka. Prawda w historii jest prawdą metaforyczną". Zob. W. Wrzosek, O myśleniu historycznym (Bydgoszcz: Oficyna Wydawnicza Epigram 2009) 26-27.

2 Oczywiście należy także wziąć pod uwagę słowa Gerharda kard. Müllera z przedmowy do tego dokumentu PKB: „Prezentowany dokument Papieskiej Komisji Biblijnej nie jest oficjalną deklaracją Magisterium Kościoła, ani nie przedstawia całej doktryny na temat natchnienia i prawdy Pisma świętego. Zawiera on jedynie wyniki wnikliwej analizy egzegetycznej tekstów biblijnych pod kątem ich pochodzenia od Boga i zawartej w nich prawdy" (s. 7). 
o Bogu i o zbawieniu człowieka jaśnieje nam (...) w Chrystusie (n. 2). Z tego stwierdzenia w Konstytucji wyciąga się wniosek: „wśród wszystkich pism biblijnych, także wśród pism Nowego Testamentu, Ewangelie zajmują słusznie miejsce najwybitniejsze. Są bowiem głównym świadectwem życia i nauki Słowa Wcielonego, naszego Zbawiciela" (n.18). Ten sam tekst soborowy potwierdza także pochodzenie apostolskie Ewangelii (ibid.): apostołowie, jako naoczni świadkowie i słudzy Słowa" (Łk 1,2) oraz ich uczniowie za pomocą spisanych świadectw Ewangelii łạcza_(collegano) Kościół z samych Chrystusem.

Konstytucja $O$ Objawieniu Bożym potwierdza nadto historyczny charakter Ewangelii: one ,podają wiernie to, co Jezus, Syn Boży, żyjąc wśród ludzi, dla wiecznego ich zbawienia, rzeczywiście uczynił i czego dokonał" (n. 19). Opisuje następnie proces, jaki doprowadził do powstania czterech Ewangelii: nie sa one zredukowane do poziomu dzieł natury symbolicznej, mitycznej, poetyckiej anonimowych autorów, ale sa godnym wiary opowiadaniem o wydarzeniach z życia i posłannictwa Jezusa. Byłoby błędem żądać, aby każdy pojedynczy element tekstu precyzyjnie odpowiadał szczegółom wydarzeń, ponieważ nie koresponduje to $\mathrm{z}$ naturą i intencją Ewangelii. Różne czynniki, które modyfikują opowiadania i tworzą różnice między nimi, nie przeszkadzają $\mathrm{w}$ wiarygodnej prezentacji wydarzeń. Za niewłaściwe należy uznać podejście, które zakłada brak ciaggłości pomiędzy Jezusem i tradycjami, które go poświadczaja, lub też brak zainteresowania czy niezdolność do przedstawienia Jezusa w sposób adekwatny. Ewangelie bowiem stanowią wiarygodny łącznik (collegamento) z prawdziwym Jezusem"3.

Cytowany fragment dokumentu Natchnienie i prawda Pisma Świętego jest w istocie eksplikacją nauczania Soboru Watykańskiego II, zawartego w konstytucji dogmatycznej o Objawieniu Bożym Dei Verbum ogłoszonej 18 listopada 1965 r., bazującej w tym względzie na Instrukcji „Sancta Mater Ecclesia” o historycznej prawdzie Ewangelii, przygotowanej przez PKB i opublikowanej 21 kwietnia 1964 r. Najnowszy dokument PKB został opublikowany w 2014 r., a zatem prawie 50 lat po Vaticanum Secundum. Pierwsze pytanie, które się rodzi jest następujące: czy biblistyka katolicka (oraz niekatolicka) i nauki humanistyczne nie wniosły nic istotnego w zakresie hermeneutyki filozoficznej i literackiej, co mogłoby przyczynić się do ukazania tematyki historycznej prawdy Ewangelii w jakiejś nowej perspektywie? Przecież w naukach humanistycznych dzieje się dziś tak wiele! Raz po raz wyrastają nowe teorie. Wszechobecny dziś postmodernizm próbuje $\mathrm{w}$ imię zachwiania fundamentami zachodniej klasycznej cywilizacji zaszczepić relatywizm poznawczy i moralny, twierdząc, że tak naprawdę wszystko jest względne i zależy od punktu widzenia ${ }^{4}$. Otóż wydaje się, że doku-

PKB, Natchnienie i prawda Pisma Świętego, 139-140 ( $\mathrm{nr} 84)$.

Zagadnienia te szeroko omówione zostały w artykule: J. Kręcidło, „Hermeneutyka i egzegeza biblijna w dobie ponowoczesności”, Scriptura Sacra 16 (2012) 47-60. 
ment Natchnienie i prawda Pisma Świętego jest odzwierciedleniem powszechnego sensus Ecclesiae, który został zdiagnozowany podczas obrad Synodu Biskupów zwołanego w 2008 r., poświęconego tematyce Słowo Boże w życiu i misji Kościoła. Podstawową drogą odpowiedzi Kościoła na ponowoczesny kryzys tożsamości kultury świata zachodniego jest podkreślenie prawdy o historycznym zakorzenieniu Bożego objawienia, będącym gwarantem prawdziwości przekazu ksiąg biblijnych. Jest to w naszym rozumieniu głównym powodem, dla którego członkowie PKB nie podejmują w dokumencie Natchnienie i prawda Pisma Świętego polemiki z ponowoczesnymi nurtami egzegezy biblijnej, lecz trzymają się wyrażonego już we wcześniejszych dokumentach (Dei Verbum) przekonania o historycznej prawdzie Bożego objawienia. Taka metodologia wydaje się być szczególnie ważna w przypadku Ewangelii, które są ,głównym świadectwem życia i nauki Słowa Wcielonego" (DV n. 18).

Aplikując powyższe treści bardziej precyzyjnie do tematu tego artykułu, należy stwierdzić, że podstawowym - i w istocie jedynym - argumentem PKB za tym, że Ewangelie są prawdziwym świadectwem Słowa Wcielonego jest ich historyczny charakter. Wiarygodność Ewangelii opiera się na historycznej pewności ciągłości przekazu na linii: historyczny Jezus - spisane świadectwo naocznych świadków o Nim. Dlaczego ta - w naszej opinii najbardziej słuszna linia argumentacji - jest tak ważna?

\section{Między historycznością a ahistorycznością}

Odnosi się wrażenie, że zarówno w naukowym dyskursie egzegetycznym, jak i w duszpasterskiej praktyce głoszenia słowa Bożego, zachodzi tendencja trzymania się jednego z dwóch biegunów - albo uznaje się, że wszystko, co zostało zapisane w Ewangeliach należy interpretować z faktograficzną dosłownością, albo też interpretuje się ewangeliczne narracje na sposób czysto literacki (symbolicznie, mitycznie, poetycko - zob. powyżej w cytowanym fragmencie dokumentu PKB), bez uwzględniania ich historycznego wymiarus.

Obydwie skrajności w podejściu do historyczności biblijnych wydarzeń prowadzą do wypaczonego rozumienia świadectwa Ewangelii o Jezusie Chrystusie Wcielonym Słowie. Upatrywanie prawdy świadectwa Ewangelii w przekonaniu o historycznej pewności najmniejszego nawet detalu znajdującego się w tekście, otwiera drogę do interpretacyjnych zafałszowań. Chodzi tu przede wszystkim o lekturę fundamentalistyczną, przed którą przestrzega dokument PKB Interpretacja Biblii

5 Bardzo trafnie ujął to napięcie prof. Krzysztof Mielcarek z KULJPII w tytule referatu wygłoszonego podczas sympozjum Stowarzyszenia Biblistów Polskich w Toruniu w dniu 24. 09. 2015 r.: „Ewangelie Dzieciństwa. Między Scyllą faktografii a Charybdą mitu”. 
$w$ Kościele ${ }^{6}$. Fundamentalistyczna historyczna dosłowność prowadzi bowiem w konieczny sposób do interpretacji nieprawdziwych, tzn. niezgodnych z pragmatycznym zamysłem autora natchnionego ${ }^{7}$. Niebezpieczeństwo faktograficznej dosłowności w odczytaniu tekstów Ewangelii może brać się również z tego, że te same wydarzenia z życia Jezusa i wypowiedziane przez Niego oraz innych bohaterów słowa, są przedstawione przez poszczególnych Ewangelistów w nieco odmiennej formie słownej. Owe rozbieżności rodzą bowiem w umyśle fundamentalistycznego czytelnika pytanie: który z Ewangelistów podaje w tym miejscu prawdziwą wersję wydarzeń i słów? Jako że nie można tutaj dać pewnej odpowiedzi, takie podejście może rodzić frustracje i zwątpienie w historyczną wiarygodność Ewangelii.

O wiele bardziej niebezpieczne i destrukcyjne dla wiary mogą być wszakże tendencje negujące lub ignorujące historyczność opowiadanych w Ewangeliach wydarzeń. Najbardziej ekstremalne jest tutaj negowanie istnienia Jezusa w ogóle. Pytanie: Did Jesus exist? powraca jak bumerang w środowiskach ludzi chcących za wszelką cenę zdyskredytować chrześcijaństwo. Wysunięta przez niemieckiego przedstawiciela heglowskiej lewicy Bruno Bauera (1809-1882) teza, że chrześcijaństwo zostało wymyślone przez Senekę, opierającego się na dziełach Filona Aleksandryjskiego, znalazła podatny grunt. W XX wieku (1910 r.) niemiecki filozof Artur Drews (1865-1935) stwierdził, że Jezus nigdy nie istniał jako historyczna postać, lecz został wymyślony na podstawie mitologii perskiej. Niemiecki asyriolog Peter Jensen (1861-1936) wysunął natomiast hipotezę, że postać Jezusa została utkana z wątków babilońskiego mitu o Gilgameszu. Obecnie najmocniej w kwestii negowania historyczności Jezusa wybrzmiewa głos amerykańskiego biblisty Roberta Price’a. Jego przypadek jest o tyle interesujący, że negując Jezusa historii, Price pozostaje praktykującym chrześcijaninem i przyjmuje Chrystusa wiary. Głos Price’a odnośnie do negacji istnienia Jezusa jako historycznej postaci jest jednak wśród współczesnych naukowców odosobniony. Mark Allan Powell, podsumowując przed kilku laty (drugie wydanie jego książki ukazało się w 2013 r.) stan badań nad historycznym Jezusem, stwierdza, że żaden poważny współczesny biblista czy też historyk czasów Nowego Testamentu nie neguje Jego istnienia ${ }^{8}$. Całość energii w kwestii historycznego Jezusa skupia się dziś na mniej lub bardziej udanych próbach rekonstrukcji Jego tożsamości. Wachlarz pomysłów historyków i egzegetów jest tutaj imponujący: od

$6 \quad$ Zob. Interpretacja Biblii w Kościele. Dokument Papieskiej Komisji Biblijnej z komentarzem biblistów polskich (tłum. i red. R. Rubinkiewiecz, Warszawa: Vocatio 1999) 54-57. Zob. też w tym samym tomie artykuł: S. Szymik, „Lektura fundamentalistyczna Biblii i zagrożenia z niej płynące w świetle dokumentu Papieskiej Komisji Biblijnej”, 169-177.

7 Autorzy dokumentu Interpretacja Biblii w Kościele ujmują to jeszcze wyraziściej, twierdząc, że lektura fundamentalistyczna prowadzi do samobójstwa myślowego (une forme de suicide de pensée).

8 Zob. M.A. Powell, Jesus as a Figure in History. How Modern Historians View the Man from Galilee (Louisville, KY: Westminster John Knox Press 2013) 251-254. 
sprowadzania tożsamości Jezusa do galilejskiego wieśniaka, poprzez uznawanie Go za proroka, charyzmatycznego Żyda, magika, mędrca, filozofa-cynika itp., do Mesjasza i Syna Bożego?.

Przekonanie o wiarygodności Ewangelii kanonicznych jako świadectwa Słowa Wcielonego bazuje na ugruntowanej przesłance, że Jezus istniał jako postać historyczna. Pytanie brzmi jednak: jaką mamy pewność, że postać ta nie została przedstawiona przez Ewangelistów niezgodnie z Jego rzeczywistą tożsamością, czyli nieprawdziwie? Czy Ewangelie są rzeczywiście prawdziwym świadectwem Wcielonego Słowa, Mesjasza, Syna Bożego?

Przez kilkanaście wieków chrześcijaństwa nikogo nie trzeba było przekonywać o wiarygodności czterech Ewangelii kanonicznych jako świadectwa o Jezusie Chrystusie posłanym na świat przez Boga, by zbawić człowieka. Nie poddawano $\mathrm{w}$ wątpliwość prawdziwości i wierności przekazu Ewangelii odnośnie do tego, kim był Jezus i czego nauczał. Począwszy od Hermanna Samuela Reimarusa (1694-1768) ${ }^{10}$ zaczęto jednak akcentować rozbieżność pomiędzy tym, kim Jezus był w rzeczywistości, a tym, w jaki sposób przedstawiony jest przez autorów Ewangelii, czyli w istocie podważać prawdziwość Ewangelii jako wiarygodnego świadectwa o Słowie Wcielonym. Od drugiej połowy osiemnastego wieku nieustannie, $\mathrm{z}$ większą lub mniejszą intensywnością, temat ten pojawia się jako jedno z kluczowych zagadnień nie tylko w dyskursie naukowym, lecz także medialnym, służąc bardzo często jako argument, mający osłabić wiarygodność chrześcijaństwa.

\section{Jeden ze współczesnych nurtów relatywizowania historycznej prawdy Ewangelii}

Na przestrzeni około dwudziestu ostatnich lat tendencje osłabiające prawdziwość świadectwa Ewangelii o Jezusie Chrystusie pojawiły się na nowo w zawoalowanej, z pozoru przyjaznej chrześcijaństwu formie. Bazując na nienowej i powszechnie uznawanej tezie o chronologicznym pierwszeństwie listów apostoła Pawła w stosunku do Ewangelii kanonicznych wysuwa się tezę, że te ostatnie są $\mathrm{w}$ istocie narratywizacją Pawłowej teologii kerygmatycznej z bogatym

9 Zob. np. syntezy współczesnych poglądów na temat Jezusa historycznego: B. Witherington III, The Jesus Quest. The Third Search for the Jew of Nazareth (Downers Grove, IL: InterVarsity Press 1997); Powell, Jesus as a Figure in History.

10 Reimarus, profesor języków orientalnych na uniwersytecie w Hamburgu, nie ogłosił za życia swojej teorii. Po jego śmierci dokonali tego jego przyjaciele. Według niego Jezus głosił nauczanie polityczne o zaprowadzeniu królestwa Bożego na ziemi. Myśliciel ten uważał, że Jezus wierzył, że jest Mesjaszem, ale tylko w sensie politycznego przywództwa w wybawieniu Żydów spod rzymskiej dominacji. Zdaniem Reimarusa, to najbliżsi uczniowie Jezusa, po Jego śmierci, uczynili z Niego Mesjasza religijnego i taki został przedstawiony w Ewangeliach. Szerzej na ten temat zob. Powell, Jesus as a Figure in History, 12-13. 
wykorzystaniem motywów z greckiej (zwłaszcza hellenistycznej) i rzymskiej literatury. Takie postawienie sprawy, choć często powodowane dobrymi intencjami (ocalmy chociaż to, co jest pewne i na tym budujmy!), uderza $\mathrm{w}$ istocie w samo serce prawdziwości świadectwa Ewangelii, podważając zasadniczy schemat przekazu Dobrej Nowiny o Słowie Wcielonym: historyczny Jezus - świadkowie Jego nauczania i cudów - spisanie ich świadectw w literackiej szacie Ewangelii. Jeżeli u podstaw prawdziwości świadectwa Ewangelii o Jezusie Chrystusie postawilibyśmy wewnętrzne doświadczenie Szawła - spotkanie Chrystusa zmartwychwstałego u bram Damaszku - a Ewangelie byłyby tylko teologiczną narratywizacją tego Pawłowego doświadczenia wyrażonego w listach, to podważylibyśmy fundament historycznej prawdy Ewangelii o Jezusie Chrystusie. Niniejszy artykuł jest reakcją sprzeciwu na tego typu tendencje oraz próbą ukazania hermeneutycznej złożoności całego zagadnienia, którego absolutnie nie można redukować do analizowania intertekstualnych literackich odniesień i wyprowadzania na tej podstawie wniosków innych niż literackie (zwłaszcza wniosków natury historycznej).

Przyjrzyjmy się argumentacji jednego z przedstawicieli tego nurtu, by następnie poddać ją krytycznej ocenie.

„W przeciwieństwie do tradycyjnego spojrzenia, utrzymywanego powszechnie we współczesnej biblistyce, najnowsze badania na temat hipertekstualności w Ewangeliach, ukazały (dosł. has revealed), że ogólnie rzecz ujmując Ewangelie nie odnoszą się do życia, czynów i słów historycznego Jezusa. Są one raczej rezultatem użycia bardzo zaawansowanej literackiej procedury sekwencyjnego hipertekstualego przepracowania listów Apostoła Pawła, a w przypadku Ewangelii Mateusza i Jana, [także] Dziejów Apostolskich, wraz z dodatkowym hipertekstualnym użyciem świętych Pism Izraela, pism Józefa [Flawiusza], i wielu innych dzieł literackich (Odyseja Homera itp.). W tym względzie Ewangelie przypominają liczne inne biblijne dzieła, zarówno Starego, jak i Nowego Testamentu. Przyjmowane powszechnie do tej pory hermeneutyczne założenie, że Ewangelie mają względnie proste, podstawowe referencyjne znaczenie (które może być analizowane poprzez rekonstrukcję ich Sitz im Leben itp.) powinno być w związku z powyższym zarzucone.

Najnowsze badania dotyczące zastosowania procedur hipertekstualności i etiopei w Ewangeliach wykazały również (has revealed), że wszystkie cztery Ewangelie kanoniczne zostały napisane przez teologicznych uczniów Pawła Apostoła. Z tego powodu, zgodnie z zasadami teologii Pawła (por. 2 Kor 5,16; Rz 1,3-4; Ga 1,15-16 itp.), Ewangelie nie przedstawiają historycznego, ,cielesnego” Jezusa, lecz raczej „duchowego” Jezusa Chrystusa, Syna Bożego, który został ukazany światu (who came to be known to the world) poprzez życie, osobę i pisma szczególnie wybranego Apostoła, i który nadal żyje w Kościele. 
Konsekwentnie, danych dotyczących historycznego Jezusa nie powinno się szukać ani w Ewangeliach kanonicznych, ani w apokryfach, lecz wyłącznie, lub prawie wyłącznie, w pismach Pawła Apostoła i Józefa Flawiusza"'11.

Należy obecnie odnieść się do kilku szczegółów z cytowanych powyżej tekstów, będących konkluzją książki ks. prof. B. Adamczewskiego Hypertextuality and Historicity in the Gospels. Autor wykorzystuje w niej tę samą metodę badawczą, którą stosował we wcześniejszej monografii $Q$ or not $Q$. The So-Called Triple, Double, and Single Traditions in the Synoptic Gospel (Peter Lang 2010) ${ }^{12}$.

Argumentacja przedstawiona przez autora cytowanej powyżej wypowiedzi wpisuje się w nurt kontestowania fundamentalnej tezy, na której bazują niemal wszyscy współcześni nowotestamentaliści - a co jeszcze ważniejsze - która stanowi podstawę wiary chrześcijan, że Ewangelie kanoniczne w sposób historycznie wiarygodny przekazują świadectwa uczniów Jezusa Chrystusa. Zachwianie owym fundamentem przekazu: historyczny Jezus - świadkowie - spisane Ewangelie, sprawia, że wiarygodność czterech kanonicznych Ewangelii jako świadectwa Słowa Wcielonego przestaje mieć znaczenie. Co autor daje nam w zamian? Hipotezę, że fundamentem chrześcijaństwa jest subiektywne doświadczenie Pawła, który osobiście najprawdopodobniej nigdy nie spotkał historycznego Jezusa. Jego świadectwo, zawarte $\mathrm{w}$ listach, pochodziło zatem $\mathrm{z}$ tego, co sam usłyszał od uczniów Jezusa (a zatem z drugiej ręki) i z jego wewnętrznej wizji objawienia mu się zmartwychwstałego Chrystusa w drodze do Damaszku. Jeżeli Ewangelie kanoniczne, jak twierdzi autor, ,nie odnoszą się do życia, czynów i słów historycznego Jezusa”, lecz są „rezultatem użycia bardzo zaawansowanej literackiej procedury sekwencyjnego, hipertekstualnego przepracowania listów Pawła Apostoła" oraz innych pism z literatury żydowskiej i hellenistyczno-rzymskiej, to należałoby je postrzegać co najwyżej w kategoriach mitu definiowanego jako narracja, w której ,znajduje się zarówno element prawdy historycznej, jak i pierwiastki fantastyczne"13. Jeżeli przyjmuje się, że chrześcijaństwo zbudowane jest na Apostole Pawle i eliminuje się tradycje ewangeliczne przekazywane przez naocznych świadków - najpierw w formie ustnej, a potem spisywane w postaci Ewangelii, z których każda podlegała sukcesywnym redakcjom, to przecina się nić łączącą Ewangelie z historycznym Jezusem. Konsekwentnie przestają one być wiarygodnym/prawdziwym świadectwem Słowa Wcielonego, a stają się subiektywnym produktem ludzkiej wyobraźni przekutej na literacki kunszt. Wydaje się, że członkowie PKB, którzy w najnowszym dokumencie z taką mocą

11 B. Adamczewski, Hypertextuality and Historicity in the Gospels (European Studies in Theology, Philosophy and History of Religions 3; Frankfurt am Main: Peter Lang 2013) 185-186.

12 Bardziej szczegółową ocenę zob. w naszej recenzji tej książki w: Collectanea Theologica 82 (2012) nr 2, 2007-2014.

13 Definicja mitu wzięta z: http://antyk.klp.pl/a-7272.html [dostęp: 01.10.2015]. 
przypominają o historycznej prawdzie Ewangelii, chcą jasno przeciwstawić się takiemu myśleniu, nie wchodząc nawet $\mathrm{z}$ nim w polemikę.

Spójrzmy jeszcze na kilka szczegółów, mających uzasadnić prawdziwość hipotezy warszawskiego biblisty. Fundamentalnym pojęciem metodologii zaproponowanej przez Bartosza Adamczewskiego jest hipertekstualność, którą pojmuje on zgodnie z systematyzacją relacji transtekstualnych zaproponowaną przez Gérarda Genette'a ${ }^{14}$. Genette wyróżnia pięć takich relacji: intertekstualnośććl ${ }^{15}$ rozumiana jako współistnienie dwóch lub więcej tekstów o ewidentnych podobieństwach - gdy jeden tekst występuje w drugim (cytaty, ewidentne aluzje, plagiaty); paratekstualność - komentarze do danego utworu obecne w nim samym w postaci tytułu, wprowadzenia czy też epilogu; metatekstualność - komentarze lub krytyczne ewaluacje odnoszące się do danego tekstu, znajdujące się w innym tekście (relacja „tekst - pretekst”); hipertekstualność - jeden tekst (hipotekst) stanowi tło dla drugiego (hipertekst); chodzi tu o imitację i adaptację motywów; architekstualność - relacje zachodzące w obrębie danego gatunku tekstu (mniej lub bardziej świadoma wierność regułom danego gatunku literackiego).

Aplikując teorię relacji transtekstualnych do piśmiennictwa nowotestamentowego, Adamczewski utrzymuje, że pomiędzy Ewangeliami a listami Pawła Apostoła zachodzi relacja hipertekstualna. Listy Pawła w tej relacji pełniły według niego funkcję hipotekstu dla Ewangelii, będących w tej relacji hipertekstem. Powtórzmy jeszcze raz słowa autora: „Najnowsze badania nad hipertekstualnością w Ewangeliach, ukazały, że ogólnie rzecz ujmując, Ewangelie nie odnoszą się do życia, czynów i słów historycznego Jezusa. Są one raczej rezultatem użycia bardzo zaawansowanej literackiej procedury sekwencyjnego przepracowania listów Apostoła Pawła”. (...). I końcowa konkluzja: „Konsekwentnie, danych dotyczących historycznego Jezusa nie powinno się szukać w Ewangeliach kanonicznych, ani w apokryfach, lecz wyłącznie, lub prawie wyłącznie, w pismach Pawła Apostoła i Józefa Flawiusza".

Gdzie tkwi podstawowy metodologiczny problem takiej procedury badawczej i dlaczego wyciągane wnioski należy ocenić jako nieuprawnione? Otóż autor metodologicznie ogranicza pole badawcze do sfery intertekstualnych, a konkretnie hipertekstualnych zależności literackich. Dlaczego takie ograniczenie? Bo te testy to konkretne źródła materialne, które możemy poddać analizie. $Z$ naszego punktu widzenia jest to jednak metodologiczne samoograniczenie. Założenie, że te teksty są jedynym pewnym źródłem historycznym wydaje się w naszej opinii niesłuszne. Systemowe wykluczenie tradycji ustnej i całej sfery zobiektywizowanej wiedzy na temat mechanizmów funkcjonowania wspólnot wczesnochrześcijańskich, którą

Zob. G. Genette, Palimpsestes: La littérature au second degré (Paris: Seuil 1982).

Należy tu odróżnić intertekstualność jako zjawisko dialogowania ze sobą motywów (fundament: teoria dialogiczności Michaiła Bachtina) nie tylko literackich od intertekstualności w zawężonym sensie w ujęciu Genette'a. 
posiadamy dzięki badaniom Sitz im Leben oraz analizom antropologicznokulturowym tamtego obszaru w owym czasie, trzeba ocenić jako nieuprawnione.

Dzięki jednak takiemu metodologicznemu samoograniczeniu, autor omawianej hipotezy uzyskuje czysto literackie pole badawcze, które uczciwie i ze znawstwem bada, analizując hipertekstualne zależności pomiędzy Ewangeliami a listami Pawła oraz inną literaturą tamtego czasu. Jak wiemy, pokrewieństw motywów pomiędzy księgami NT i ST, czy też pomiędzy motywami zawartymi w obydwu testamentach a wcześniejszą literaturą cywilizacji basenu Morza Śródziemnego jest bardzo duże, i bibliści od dawna chętnie się do nich odwołują, nierzadko postulując, że taki czy inny motyw biblijny został zapożyczony z literatury wcześniejszej. Takim badaniom towarzyszy jednak zawsze świadomość, że przekaz Bożego objawienia absolutnie nie ogranicza się do tego typu relacji. Podstawą dla powstawania świętych ksiąg ST i NT, a zwłaszcza Ewangelii, nie była chęć pisarskiego „wykazania się" autorów ksiąg - ich literackiego geniuszu w imitowaniu i adaptowaniu wcześniejszych motywów (istota hipertekstualności) - lecz doświadczenie zbawczej obecności Boga w ich codziennym życiu. Doświadczenie wiary w Bożą zbawczą obecność w codzienności i historii narodu Bożego wybrania, a następnie wspólnot wczesnochrześcijańskich oraz nieodparta potrzeba dawania świadectwa tej wiary innym, stoi u podstaw tradycji ustnej, która przybrała następnie formę pisemną.

Ewangelie są zatem na pierwszym miejscu spisanym świadectwem zbawczej aktywności Słowa Wcielonego w świecie, a dopiero w konsekwencji dziełem literackim. Ignorowanie tej fundamentalnej perspektywy, którą pielęgnował Kościół od pierwszych chwil swego istnienia i która ze stanowczością została przywołana przez PKB w dokumencie Natchnienie i prawda Pisma Świętego, jest metodologicznie nieuprawnione. Zawężając horyzont badawczy do obserwacji hipertekstualnych czy szerzej intertekstualnych zależności pomiędzy tekstami, a zatem opierając się tylko na danych literackich, jest się uprawnionym jedynie do wyciągania wniosków o pokrewieństwach literackich. Eliminowanie z obszaru badawczego przesłanek natury historycznej, w tym zwłaszcza tradycji ustnej, nie upoważnia badacza literackich zależności do wyciągania wniosków natury historycznej.

\section{Jaka prawda Ewangelii o Wcielonym Słowie?}

Józef Ratzinger, późniejszy papież Benedykt XVI, stwierdził kiedyś, że „prawomocność danej hermeneutyki polega na jej mocy wyjaśniającej”'16. Innymi słowy, bardziej prawdziwa jest ta hermeneutyka, przy użyciu której egzegeta

16 Zob. J. Ratzinger, Patrzeć na przebitego. Szkice o chrystologii duchowej (tłum. J. Merecki) (Kraków: Wydawnictwo Salwator 2008) 41. 
może więcej wyjaśnić. Spojrzenie to bazuje na hermeneutyce Hansa-Georga Gadamera, który kwestionuje słuszność stosowania pooświeceniowego paradygmatu nauki do nauk humanistycznych ${ }^{17}$. W opinii Gadamera żaden badacz historycznej przeszłości nie może rościć sobie prawa do neutralności i obiektywności badawczej, gdyż - świadomie lub nie - zawsze kieruje się subiektywnym przedrozumieniem. W związku z tym naukowiec powinien zawsze podchodzić z dystansem do swoich pomysłów, zakładając, że ,inny może wiedzieć więcej”18. Tym innym według Gadamera jest tradycja. Dla Gadamera podstawowym medium, w którym następuje zlanie się horyzontów (Horizontverschmelzung) jest rozmowa. Tekst natomiast stawowi samoalienację rozmowy. Prawda historyczna przekazywana jest $\mathrm{w}$ rozmowie, którą $\mathrm{w}$ naszym przypadku należałoby identyfikować z przekazem tradycji ustnych o Jezusie przez świadków Jego słów i czynów. Owe gadamerowskie przesłanki podejmuje w swojej hermeneutyce filozoficznej Paul Ricoeur, który jednak skupia się już na tekście rozumianym jako materialne utrwalenia mowy/tradycji ${ }^{19}$.

Kluczowe dla naszego rozumienia Ewangelii jako prawdziwych świadectw Słowa Wcielonego jest traktowanie ich jako materialnego zapisu świadectwa przekazanego przez wiarygodnych świadków. Z punktu widzenia egzegety-interpretatora, autorytet tradycji należy rozumieć bardzo szeroko - jako przekaz ustny Dobrej Nowiny, jako aktywność redakcyjną w kolejnych relekturach spisanego już tekstu we wspólnocie wiary, jako kierunek interpretacji ustabilizowanego tekstu Ewangelii przez Ojców Apostolskich, Ojców Kościoła oraz Magisterium Kościoła wszystkich wieków. To właśnie autorytet tradycji interpretacyjnej wskazuje badaczowi przeszłości - w naszym przypadku Ewangelii - właściwy kierunek interpretacji i poszukiwania prawdy. Ma on o wiele większa wartość niż najbardziej nawet kreatywne pomysły egzegetów.

Gadamer wprowadza również w swoim opus magnum Warheit und Methode rozróżnienie pomiędzy wyjaśnieniem a rozumieniem ${ }^{20}$. Aplikując te pojęcia do egzegezy biblijnej, trzeba powiedzieć, że zwłaszcza nurt historyczno-krytyczny dąży do wyjaśnienia tekstu i na nim się zatrzymuje. Dla Gadamera samo wyjaśnienie - choćby najbardziej nawet głębokie i szczegółowe - jest tylko etapem do poznania prawdy. Natomiast rozumienie sensu tekstu z przeszłości powinno

17 Postulatu referowane tutaj zostały zamieszczone w monografii: H.-G. Gadamer, Prawda i meto$d a$ (tłum. B. Baran) (Warszawa: Wydawnictwo Naukowe PWN 2013). Pierwsze wydanie jako: Wahrheit und Methode. Grundzüge einer philosophischen Hermeneutik (Tübingen: Mohr Siebeck 1975).

18 Szerzej: Gadamer, Prawda i metoda, 382-392.

19 Spośród licznych publikacji Paula Ricoeura polecamy: Język, tekst, interpretacja. Wybór pism (wybrała i wstępem opatrzyła K. Rosner, tłum. P. Graff - K. Rosner) (Warszawa: Państwowy Instytut Wydawniczy 1989). Na temat relacji „mowa - tekst” zobacz zwłaszcza pierwszą część: strony 63-187.

20 Zob. Gadamer, Prawda i metoda, 280-288. 
odbywać się z uwzględnieniem jego dialogu z tradycją oraz ze świadomością, że każdy akt rozumienia jest zarazem aktem formującym interpretatora.

Gadamerowska i ricoeurowska hermeneutyka filozoficzna (plus hermeneutyka literacka Ricoeura) wpłynęły, w naszej opinii, w dużym stopniu na zasady egzegezy katolickiej zaproponowane przez papieża Benedykta XVI w posynodalnej adhortacji apostolskiej Verbum Domini ${ }^{21}$ ogłoszonej 11 listopada 2010 r. Papież przypomniał egzegetom katolickim, jakimi przesłankami hermeneutycznymi rządzi się Kościół w interpretacji Pisma Świętego ${ }^{22}$. Benedykt XVI wyraźnie zrywa z pooświeceniowym mitem neutralności i obiektywności badacza, ukazując Kościół jako właściwe miejsce interpretacji Bibliii ${ }^{23}$. Przyjmowanie autorytetu Kościoła jako środowiska wyjaśniania tekstów biblijnych implikuje również uznanie przez egzegetę autorytetu Tradycji interpretacyjnej Kościoła. Jedyną właściwą metodą interpretacji ksiąg biblijnych jest zastosowanie założeń i intencji, które towarzyszyły powstawaniu danego pisma ${ }^{24}$. Skoro pisma te nie rodziły się przede wszystkim jako dzieła literackie, lecz jako zapis i świadectwo wiary tamtych ludzi po to, by wzbudzać wiarę $\mathrm{w}$ innych, to hermeneutyka wiary jest jedyną właściwą hermeneutyką dla ich adekwatnej interpretacji $\mathrm{i}^{25}$.

\section{Wniosek końcowy}

W takiej perspektywie hermeneutycznej Ewangelie są niewątpliwie prawdziwym świadectwem Słowa Wcielonego. Przekonanie to wynika z pewności co do wierności przekazu tradycji o historycznym Jezusie przez świadków. Tradycje te przyjęły następnie formę spisaną - jednak nie przede wszystkim jako utwór literacki, lecz jako wierne zarejestrowanie świadectwa wiary, którą świadkowie chcieli przekazać i zaszczepić w następnych pokoleniach. Ewangelie, będąc świadectwem wiary, domagają się od czytelnika/interpretatora wszystkich czasów zastosowania hermeneutyki adekwatnej do tej, która przyświecała ich powstawaniu - musi to być również hermeneutyka wiary. Tylko taka hermeneutyka pozwala interpretatorowi uniknąć fundamentalnego metodologicznego błędu

21 Zob. Benedykt XVI, Adhortacja apostolska Verbum Domini. O Słowie Bożym w życiu i misji Kościoła (Kraków: Wydawnictwo M 2010).

22 Drugi element pierwszej części (numery 29-49).

23 Verbum Domini, 29-30.

24 Zob. tamże, 19: Papież przypomina, że interpretacja powinna „uwzględniać ducha, w którym [dana księga - dodatek własny] została napisana".

25 Inspiracją były tu zapewne prace twórcy podejścia kanonicznego Brevarda Childsa, zwłaszcza pozycje: Biblical Theology in Crisis (Philadelphia: Westminster Press 1970); Introduction to the Old Testament as Scripture (London: SCM 1979); The New Testament as Canon: An Introduction (London: SCM 1984); Old Testament Theology in a Canonical Context (London: SCM 1985). 
i prawdziwie zrozumieć objawione w Ewangeliach Słowo Wcielone. Każde inne podejście egzegety prowadzić będzie do wyjaśnienia tekstu, ale nie do jego zrozumienia.

\section{Bibliografia}

Adamczewski, B., $Q$ or not $Q$. The So-Called Triple, Double, and Single Traditions in the Synoptic Gospel (Frankfurt am Main - New York: Peter Lang 2010).

Adamczewski B., Hypertextuality and Historicity in the Gospels (European Studies in Theology, Philosophy and History of Religions 3; Frankfurt am Main: Peter Lang 2013).

Benedykt XVI, Adhortacja apostolska Verbum Domini. O Stowie Bożym w życiu i misji Kościoła (Kraków: Wydawnictwo M 2010).

Childs B., Biblical Theology in Crisis (Philadelphia: Westminster Press 1970).

Childs B., Introduction to the Old Testament as Scripture (London: SCM 1979).

Childs B., The New Testament as Canon: An Introduction (London: SCM 1984).

Childs B., Old Testament Theology in a Canonical Context (London: SCM 1985).

Gadamer H.-G., Wahrheit und Methode. Grundzüge einer philosophischen Hermeneutik (Tübingen: Mohr Siebeck 1975) (polski przekład: Prawda i metoda [tłum. B. Baran] [Warszawa: Wydawnictwo Naukowe PWN 2013]).

Genette G., Palimpsestes: La littérature au second degré (Paris: Seuil 1982).

Interpretacja Biblii w Kościele. Dokument Papieskiej Komisji Biblijnej z komentarzem biblistów polskich (tłum. i red. R. Rubinkiewiecz) (Warszawa: Vocatio 1999).

Kręcidło J., „Hermeneutyka i egzegeza biblijna w dobie ponowoczesności”, Scriptura Sacra 16 (2012) 47-60

Papieska Komisja Biblijna, Natchnienie i prawda Pisma Świętego. Stowo, które od Boga pochodzi i mówi o Bogu, aby zbawić świat (Kielce: Verbum 2014).

Powell M.A., Jesus as a Figure in History. How Modern Historians View the Man from Galilee (Louisville, KY: Westminster John Knox Press 2013).

Ratzinger J., Patrzeć na przebitego. Szkice o chrystologii duchowej (tłum. J. Merecki) (Kraków: Wydawnictwo Salwator 2008).

Ricouer P., Język, tekst, interpretacja. Wybór pism (wybrała i wstępem opatrzyła K. Rosner, thum. P. Graff - K. Rosner) (Warszawa: Państwowy Instytut Wydawniczy 1989).

Szymik S., „Lektura fundamentalistyczna Biblii i zagrożenia z niej płynące w świetle dokumentu Papieskiej Komisji Biblijnej”, Interpretacja Biblii w Kościele. Dokument Papieskiej Komisji Biblijnej z komentarzem biblistów polskich (przekład i red. R. Rubinkiewicz) (Warszawa: Vocatio 1999) 169-177.

Witczyk H., „Natchnienie i prawda Pisma Świętego - nowe perspektywy”, Biblia w teologii fundamentalnej (red. J. Perszon) (Toruń: Wydawnictwo Naukowe Uniwersytetu Mikołaja Kopernika 2010) 161-179.

Witherington III B., The Jesus Quest. The Third Search for the Jew of Nazareth (Downers Grove, IL: InterVarsity Press 1997).

Wrzosek W., O myśleniu historycznym (Bydgoszcz: Oficyna Wydawnicza Epigram 2009). 
